\title{
Author Correction: Divergent effects of Wnt/ $\beta$-catenin signaling modifiers on the preservation of human limbal epithelial progenitors according to culture condition
}

\author{
Hyun Jung Lee ${ }^{1}$, J. Mario Wolosin² \& So-Hyang Chung ${ }^{1}$ \\ 2017 \\ The Acknowledgements section in this Article is incomplete.
}

Correction to: Scientific Reports https://doi.org/10.1038/s41598-017-15454-x, published online 10 November

“This work was supported by a grant from the Korea Health Technology R\&D Project, Ministry of Health \& Welfare, Republic of Korea, HI14C1607 (S-HC), an NIH/NEI RO1-EY014878 and an unrestricted grant from RPB, Inc. (JMW)."

should read:

“This work was supported by a grant from the Korea Health Technology R\&D Project, Ministry of Health \& Welfare, Republic of Korea, HI14C1607 and by the National Research Foundation of Korea(NRF) grant funded by the Korea government(MSIP) (No. 2017R1A2B4012327) (S-HC), an NIH/NEI RO1-EY014878 and an unrestricted grant from RPB, Inc. (JMW)."

(c) Open Access This article is licensed under a Creative Commons Attribution 4.0 International Cicense, which permits use, sharing, adaptation, distribution and reproduction in any medium or format, as long as you give appropriate credit to the original author(s) and the source, provide a link to the Creative Commons license, and indicate if changes were made. The images or other third party material in this article are included in the article's Creative Commons license, unless indicated otherwise in a credit line to the material. If material is not included in the article's Creative Commons license and your intended use is not permitted by statutory regulation or exceeds the permitted use, you will need to obtain permission directly from the copyright holder. To view a copy of this license, visit http://creativecommons.org/licenses/by/4.0/.

(C) The Author(s) 2018

${ }^{1}$ Department of Ophthalmology and Visual Science, Catholic Institute of Visual Science, College of Medicine, The Catholic University of Korea, Seoul St. Mary's Hospital, Seoul, Republic of Korea. ${ }^{2}$ Department of Ophthalmology, Eye and Vison Research Institute and Black Family Stem Cell Institute, Icahn School of Medicine at Mount Sinai, New York, NY, United States of America. Correspondence and requests for materials should be addressed to J.M.W. (email: jmario.wolosin@mssm.edu) or S.-H.C. (email: chungsh@catholic.ac.kr) 